\title{
Disruptive Effects of Some Novel Chitin Synthesis Inhibitors on the Transaminase Activity in Larval Tissues of Spodoptera littoralis (Lepidoptera: Noctuidae)
}

\author{
Mohammad Tanani, Karem Ghoneim*, Khalid Hamadah, Ahmad Basiouny, \\ Hassan Waheeb
}

Faculty of Science, Al-Azhar University, Cairo, Egypt

*karemghoneim@gmail.com,kar_ghoneim@yahoo.com

\begin{abstract}
Objective of the present study was to investigate the effects of novel CSIs, viz., Novaluron, Cyromazine, and Diofenolan, on the activities of glutamic oxaloacetic (GOT) and glutamc pyruvic (GPT) transaminases in larval haemolymph and fat bodies of the economically dangerous insect, Spodoptera littoralis. $L C_{50}$ of each CSI (2.71, 74.44 and 7.65 ppm, respectively) was applied on the penultimate instar larvae and the enzyme activities were determined in the successfully moulted last instar larvae of different ages. Cyromazine and Diofenolan exhibited a prevalent enhancing effect on GOT activity in haemolymph of larvae of all ages. Novaluron exhibited a similar inducing effect on the enzyme activity except in 4-day old larvae. With regard to fat bodies, remarkably decreasing GOT activity was determined in larvae of all ages, regardless the CSI. Regarding GPT activity, CSIs exhibited contradictory effects in haemolymph of larvae since Novaluron elaborately promoted it, with an exceptional case of 6-day old larvae while Cyromazine and Diofenolan treatments resulted in conspicuously declined enzyme level, with few exceptions. Dealing with fat bodies, Cyromazine and Diofenolan enhanced the enzyme activity while Novaluron failed to exhibit an effect, irrespective of the larval age.
\end{abstract}

Keywords: Cyromazine, Diofenolan, fat body, glutamate oxaloacetate transaminase, glutamate pyruvate transaminase, haemolymph, larva, Novaluron

\section{INTRODUCTION}

Several conventional synthetic insecticides have been used to control the population of Egyptian cotton leafworm, Spodoptera littoralis (Boisduval) (Lepidoptera: Noctuidae). Over the last three decades, the intensive use of broad-spectrum insecticides against this pest has led to the development of resistance against many registered pesticides, detrimental effects on the natural enemies, pollinators and all other non-target insects, and serious toxicological problems to humans and the environment [1-7]. Consequently, alternative ways of controlling S. littoralis are very important. In this regard, insect growth regulators (IGRs) have captured the interest of entomologists [8]. At present, using IGRs is considered as the possible alternative way of synthetic insecticides for controlling this pest [9].

IGRs are considered as the possible alternative way of conventional insecticides for controlling $S$. littoralis [10] because they differ widely from the commonly used insecticides, as they exert their insecticidal effects through their influence on development, metamorphosis and reproduction of the target insects by disrupting the normal activity of the endocrine system [11]. IGRs can be grouped according to their mode of action as chitin synthesis inhibitors (CSIs) and substances that interfere with the action of insect hormone (i.e. juvenile hormone analogues, ecdysteroids) [12].

Novaluron is a relatively new benzoylphenyl urea CSI with good activity against the Colorado potato beetle [13, 14] and low mammalian toxicity [15]. As reported by many authors [16-41], Novaluron inhibits the chitin formation in larvae of various insects classified in Lepidoptera, Coleoptera, Homoptera and Diptera. This CSI generally is selective in favor of non-target organisms, such as natural enemies [42]. Also, it has no cross-resistance with conventional insecticides, the juvenile hormone mimic pyriproxyfen and neonicotinoids [43]. Cyromazine is a triazine IGR used as alternative to insecticides and acaricides. As reported by many authors [44-60], Cyromazine exhibited various degrees of success for controlling different pests such as flies, stored product insect pests and 
leafminers. It is harmless to parasitoids [61, 62] as well as to mammalian and poultry [63]. Because of its inhibitory effects on the moulting process, it is possible to suggest that the mode of action is related to the developmental hormone, 20-hydroxyecdysone. However, the precise mode of Cyromazine action remains unknown [64]. Diofenolan is a CSI used for the control of several pests, such as lepidopterous species and scale insects [65- 67], Papilio demoleus [68], Musca domestica [69-72], Rhynchophorus ferrugineus [73] and Schistocerca gregaria [74-77]. It did not affect the survival of beneficial parasitoids and predators of some pests such as Chrysoperla carnea [78].

Transamination has been demonstrated in a number of insect tissues, particularly that concerning glutamate, aspartate and alanine [79]. The Glutamic oxaloacetic transaminase (GOT, official name: aspartate aminotransferase, AST) and Glutamic pyruvic transaminase (GPT, official name: alanine aminotransferase, ALT) are key enzymes in the formation of non-essential amino acids, in metabolism of nitrogen waste, gluconeogenesis and correlated with protein anabolism and catabolism [80]. Moreover, transaminases, especially GPT, acts as a catalytic agent in carbohydrates metabolism [81].

The noctuid S. littoralis is distributed throughout the world but it is native to Africa [82]. It is a serious or major pest of cultivated crops primarily in tropical and subtropical regions, in Africa, Southern Europe, Middle East and Asia Minor [83] and the Mediterranean area [84-89]. Objective of the present study was to investigate the effects of novel CSIs, viz. Novaluron, Cyromazine and Diofenolan, on the GOT and GPT activities in two larval tissues of this economically major pest.

\section{MATERIALS AND MethodS}

\subsection{Experimental Insect}

A sample of $S$. littoralis pupae was kindly obtained from the culture of susceptible strain maintained for several generations in Plant Protection Research Institute, Agricultural Research Center, Doqqi, Giza, Egypt. In laboratory of Entomology, Faculty of Science, Al-Azhar University, Cairo, a culture was reared under laboratory controlled conditions $\left(27 \pm 2^{\circ} \mathrm{C}, 65 \pm 5 \%\right.$ R.H., photoperiod $14 \mathrm{~h} \mathrm{~L}$ and $10 \mathrm{~h}$ D). Rearing procedure was carried out according to Ghoneim [90] and improved by Bakr et al. [91]. Larvae were provided daily with fresh castor bean leaves Ricinus communis. The emerged adults were provided with $10 \%$ honey solution on a cotton wick as a food source. Moths were allowed to lay eggs on branches of Nerium oleander, then the egg patches were collected daily, and transferred into Petri dishes for another generation.

\subsection{Larval Treatments with CSIs}

Novaluron (Rimon, Pestanal ${ }^{\circledR}$ ) [1-[chloro-4-(1,1,2-trifluoromethoxyethoxy) phenyl] -3-(2,6-difluor obenzoyl) urea] was purchased from Sigma-Aldrich Chemicals (https://www.sigmaaldrich.com), Cyromazine (Larvadex, Trigard, Vetrazin) [N-cyclopropyl-1, 3, 5-triazine-2, 4, 6-triamine] was purchased from Sigma-Aldrich Chemicals (https://www.sigmaaldrich.com) and Diofenolan (CGA 59205, Aware $\left.{ }^{\circledR}\right)$ [2-ethyl-4-[(4-phenoxyphenoxy) methyl]-1,3-dioxolane] was obtained by Agricultural research center, laboratory of pesticides, Doqqi, Giza, Egypt. In a preliminary experiment, $\mathbf{L C}_{\mathbf{5 0}}$ values of Novaluron, Cyromazine and Diofenolan were calculated, after treatment of penultimate instar larvae of S. littoralis, in 2.71, 74.44 and $7.65 \mathrm{ppm}$, respectively. After treatment of these larvae with $\mathrm{LC}_{\mathbf{5 0}}$ of each compound, GOT and GPT activities were determined in haemolymph and fat bodies of the successfully moulted last instar larvae of different ages.

\subsection{Larval Tissue Preparation}

\subsubsection{Haemolymph}

For the determination of the enzyme activities, haemolymph was collected from treated and control last instar larvae of different ages (0-, 2-, 4-, and 6-day old). The haemolymph was obtained by amputation of one or two prothoracic legs of the larva with fine scissors. Gentle pressure was done on the thorax until a drop of haemolymph appeared at the point of amputation. Haemolymph was drawn into Eppendorff Pipetman containing few milligrams of phenoloxidase inhibitor (Phenylthiourea) to prevent tanning or darkening and then diluted $5 \times$ with saline solution $0.7 \%$. The diluted haemolymph was frozen for $20 \mathrm{~s}$ to rupture the haemocytes. Collected haemolymph samples were then centrifuged at 2000 r.p.m. for $5 \mathrm{~min}$, and only the supernatant fractions were used for assay directly or frozen until use. Three replicates were used and the haemolymph of two individuals were never mixed. 


\subsubsection{Fat Body}

For the determination of the enzyme activities, fat bodies (parietal and visceral) were carefully collected from the treated and control last instar larvae of the same ages. Collected samples of fat bodies were weighed and then homogenized in a saline solution (the fat body of one insect / $1 \mathrm{ml}$ saline solution $0.7 \%$ ) using a fine electric homogenizer, tissue grinder for $2 \mathrm{~min}$. Homogenates were centrifuged at 4000 r.p.m. for $15 \mathrm{~min}$. The supernatant was used directly or frozen until use. Three replicates were used and the fat bodies from two individuals were avoided to be mixed.

\subsection{Determination of Transaminase Activities}

GOT and GPT activities were determined in the larval tissues according to the method of Harold [92] using a kit of Bioadwic. The enzyme was measured at wave length $546 \mathrm{~nm}$ by spectrophotometer.

\subsection{Statistical Analysis of Data}

Data obtained were analyzed by the Student's $t$-distribution, and refined by Bessel correction [93] for the test significance of difference between means.

\section{RESUlts}

\subsection{Effects on GOT Activity}

Depending on the data arranged in Table (1), Novaluron enhanced larvae during the first half of the instar to gain elevated level of GOT in haemolymph (27.28 and $21.43 \%$ increments in 0- and 2-day old larvae, respectively) but prohibited larvae of 4-day old in significantly reduced enzyme activity (28.33 \pm 1.03 , compared to $31.67 \pm 2.12 \mathrm{U} / \mathrm{mL}$ of control larvae) and failed to affect the late-aged ones. With regard to Cyromazine, data of Table (2) clearly show a strong prevalent inducing effect since the enzyme activity was unexceptionally increased in haemolymph $(72.78,42.86,15.79$ and $25.02 \%$ increments in 0-, 2-, 4- and 6-day old larvae, respectively). As obviously seen in Table (3), Diofenolan failed to affect GOT activity in haemolymph of newly moulted larvae but promoted other larvae to gain slightly or considerably increasing activity $(14.32,5.24$ and $25.02 \%$ increments in 2-, 4and 6-day old larvae, respectively).

In connection with the GOT activity in fat bodies, data assorted in the previously mentioned tables exiguously reveal a powerful prohibiting action of all compounds on larvae of all ages to achieve remarkably decreasing GOT activity. In some detail, the enzyme activity was pronouncedly decreased in 47.37, 50.11, 48.00 and $28.55 \%$ reductions in larvae of 0-, 2-, 4- and 6-day old, respectively, in case of Novaluron (see Table 1). Cyromazine caused 57.89, 50.01, 48.00 and 28.55\% reductions in larvae of the same ages, respectively (Table 2). Also, Diofenolan treatment resulted in tremendously declined GOT activity $(42.10,32.14,32.01$ and $21.43 \%$ reductions in larvae of the same ages, respectively (Table 3).

\subsection{Effects on GPT Activity}

According to data presented in Table (4), Novaluron promoted 0-, 2- and 4-day old larvae to obtain slightly or considerably raising GPT level $(0.69,100.05$ and $5.24 \%$ increments, respectively) but lateaged ones were prohibited to attain normal level of GPT activity (30.0\% reduction). After treatment with Cyromazine, data of determined GPT activity were listed in Table (5). Depending on these data, GPT activity was conspicuously elevated in haemolymph of only 2-day old larvae $(41.67 \pm 1.11$, compared to $18.33 \pm 1.18 \mathrm{U} / \mathrm{mL}$ of control larvae) but remarkably decreased in other larvae (23.60, 15.79 and $45.00 \%$ reductions in $0-$, 4- and 6-day old larvae, respectively). As evidently shown in Table (6), Diofenolan failed to affect the GPT activity in haemolymph of 2-day old larvae but insignificantly or significantly inhibited it in larvae of other ages $(65.27,31.58$ and $19.98 \%$ reductions in 0-, 4- and 6-day old larvae, respectively).

In respect of fat bodies, Novaluron exhibited no effect on larvae of 0-, 2- and 6-day old but stimulated 4-day old larvae to achieve elaborately high level of GPT $(91.67 \pm 3.14$ vs. $83.33 \pm 1.88 \mathrm{U} / \mathrm{mL}$ of control larvae, see Table 4). A predominant enhancing effect was exhibited by both Cyromazine and Diofenolan on larvae of all ages to gain increasing GPT activity. In some detail, Cyromazine treatment resulted in 30.22, 31.92, 36.00 and $1.13 \%$ increments in fat bodies of 0-, 2-, 4- and 6-day old larvae, respectively (see Table 5) and Diofenolan treatment resulted in 30.22, 57.45, 78.00 and $3.41 \%$ increments in fat bodies of the congeners, respectively (see Table 6). 
Mohammad Tanani et al.

Table1. GOT Activity in Last Instar Larvae of S. littoralis after Treatment with $L_{C_{50}}$ of Novaluron

\begin{tabular}{|c|c|c|c|c|c|c|}
\hline \multirow{2}{*}{\multicolumn{3}{|c|}{ Tissue }} & \multicolumn{4}{|c|}{ Larval age } \\
\hline & & & 0-day old & 2-day old & 4-day old & 6-day old \\
\hline \multirow{4}{*}{ Treated } & \multirow{2}{*}{ Haemolymph (U/ml) } & mean \pm SD & $23.33 \pm 2.89 \mathrm{~d}$ & $28.33 \pm 1.03 \mathrm{~d}$ & $28.33 \pm 1.03 \mathrm{~b}$ & $33.33 \pm 2.00 \mathrm{a}$ \\
\hline & & Change (\%) & +27.28 & +21.43 & -10.55 & 0.00 \\
\hline & \multirow{2}{*}{ Fat body (U/ml) } & mean \pm SD & $33.33 \pm 0.88 \mathrm{~d}$ & $23.33 \pm 2.89 \mathrm{~d}$ & $21.67 \pm 1.61 \mathrm{~d}$ & $16.67 \pm 1.75 \mathrm{~d}$ \\
\hline & & Change (\%) & -47.37 & -50.11 & -48.00 & -28.55 \\
\hline \multirow{2}{*}{ Control } & Haemolymph (U/ml) & mean \pm SD & $18.33 \pm 1.13$ & $23.33 \pm 0.93$ & $31.67 \pm 2.12$ & $33.33 \pm 1.50$ \\
\hline & Fat body $(\mathrm{U} / \mathrm{ml})$ & mean \pm SD & $63.33 \pm 2.22$ & $46.67 \pm 1.17$ & $41.67 \pm 1.01$ & $23.33 \pm 0.66$ \\
\hline
\end{tabular}

Mean $\pm S D$ followed with the letter $(a)$ : insignificantly different $(P>0.05)$, $(b)$ : significantly different $(P<0.05)$, $(d)$ : very highly significantly different $(P<0.001)$.

Table2. GOT Activity in Last Instar Larvae of S. littoralis after Treatment with $L C_{50}$ of Cyromazine

\begin{tabular}{|c|c|c|c|c|c|c|}
\hline \multirow{2}{*}{\multicolumn{3}{|c|}{ Tissue }} & \multicolumn{4}{|c|}{ Larval age } \\
\hline & & & 0-day old & 2-day old & 4-day old & 6-day old \\
\hline \multirow{4}{*}{ Treated } & \multirow{2}{*}{$\begin{array}{l}\text { Haemolymph } \\
(\mathrm{U} / \mathrm{ml})\end{array}$} & mean \pm SD & $31.67 \pm 1.45 \mathrm{~d}$ & $33.33 \pm 2.04 \mathrm{~d}$ & $36.67 \pm 2.88 \mathrm{c}$ & $41.67 \pm 2.13 \mathrm{~d}$ \\
\hline & & Change (\%) & +72.78 & +42.86 & +15.79 & +25.02 \\
\hline & \multirow{2}{*}{ Fat body $(\mathrm{U} / \mathrm{ml})$} & mean \pm SD & $26.67 \pm 2.80 \mathrm{~d}$ & $23.38 \pm 0.96 \mathrm{~d}$ & $21.55 \pm 1.75 \mathrm{~d}$ & $16.44 \pm 0.75 \mathrm{~d}$ \\
\hline & & Change (\%) & -57.89 & -50.01 & -48.00 & -28.55 \\
\hline \multirow[t]{2}{*}{ Control } & $\begin{array}{l}\text { Haemolymph } \\
(\mathrm{U} / \mathrm{ml})\end{array}$ & mean \pm SD & $18.33 \pm 1.13$ & $23.33 \pm 0.93$ & $31.67 \pm 2.12$ & $33.33 \pm 1.50$ \\
\hline & Fat body $(\mathrm{U} / \mathrm{ml})$ & mean \pm SD & $63.33 \pm 2.22$ & $46.67 \pm 1.17$ & $41.67 \pm 1.01$ & $23.33 \pm 0.66$ \\
\hline
\end{tabular}

(c): highly significantly different $(P<0.005)$. $(d)$ : See footnote of Table (1).

Table3. GOT Activity in Last Instar Larvae of S. littoralis after Treatment with $L_{50}$ of Diofenolan

\begin{tabular}{|c|c|c|c|c|c|c|}
\hline \multicolumn{2}{|c|}{ Tissue } & \multicolumn{5}{c|}{ Larval age } \\
\cline { 3 - 7 } & \multirow{4}{*}{ Treated } & 0-day old & 2-day old & 4-day old & 6-day old \\
\cline { 3 - 7 } & \multirow{3}{*}{ Faemolymph (U/ml) } & mean \pm SD & $18.33 \pm 0.66 \mathrm{a}$ & $26.67 \pm 1.46 \mathrm{c}$ & $33.33 \pm 1.04 \mathrm{a}$ & $41.67 \pm 2.00 \mathrm{~d}$ \\
\cline { 3 - 7 } & & Change (\%) & 0.00 & +14.32 & +5.24 & +25.02 \\
\hline \multirow{2}{*}{ Control } & Haemolymph (U/ml) & mean \pm SD & $18.33 \pm 1.13$ & $23.33 \pm 0.93$ & $31.67 \pm 2.12$ & $33.33 \pm 1.50$ \\
\cline { 3 - 7 } & Fat body (U/ml) & mean \pm SD & $63.33 \pm 2.22$ & $46.67 \pm 1.17$ & $41.67 \pm 1.01$ & $23.33 \pm 0.66$ \\
\hline
\end{tabular}

(a), (d): See footnote of Table (1). (c): See footnote of Table (2).

Table4. GPT Activity in Last Instar Larvae of S. littoralis after Treatment with $L_{50}$ of Novaluron

\begin{tabular}{|c|c|c|c|c|c|c|}
\hline \multirow{2}{*}{\multicolumn{3}{|c|}{ Tissue }} & \multicolumn{4}{|l|}{\begin{tabular}{|l|} 
Larval age \\
\end{tabular}} \\
\hline & & & 0-day old & 2-day old & 4-day old & 6-day old \\
\hline \multirow{4}{*}{ Treated } & \multirow{2}{*}{ Haemolymph (U/ml) } & mean \pm SD & $48.33 \pm 1.55 \mathrm{a}$ & $36.67 \pm 2.66 \mathrm{~d}$ & $33.33 \pm 0.96 \mathrm{a}$ & $23.33 \pm 0.89 \mathrm{a}$ \\
\hline & & Change (\%) & +0.69 & +100.05 & +5.24 & -30.00 \\
\hline & \multirow{2}{*}{ Fat body (U/ml) } & mean \pm SD & $71.67 \pm 2.45 \mathrm{a}$ & $78.33 \pm 1.68 \mathrm{a}$ & $91.67 \pm 3.14 \mathrm{~b}$ & $146.67 \pm 2.67 \mathrm{a}$ \\
\hline & & Change (\%) & 0.00 & 0.00 & +10.01 & 0.00 \\
\hline \multirow{2}{*}{ Control } & Haemolymph (U/ml) & mean \pm SD & $48.00 \pm 2.89$ & $18.33 \pm 1.18$ & $31.67 \pm 1.37$ & $33.33 \pm 2.16$ \\
\hline & Fat body (U/ml) & mean \pm SD & $71.67 \pm 3.18$ & $78.33 \pm 2.89$ & $83.33 \pm 1.88$ & $146.67 \pm 2.67$ \\
\hline
\end{tabular}

(a), (b), (d): See footnote of Table (1).

Table5. GPT Activity in Last Instar Larvae of S. littoralis after Treatment with LC $C_{50}$ of Cyromazine

\begin{tabular}{|c|c|c|c|c|c|c|}
\hline \multirow{2}{*}{\multicolumn{3}{|c|}{ Tissue }} & \multicolumn{4}{|l|}{ Larval age } \\
\hline & & & \multirow{2}{*}{$\begin{array}{l}\text { 0-day old } \\
36.67 \pm 2.89 \mathrm{~d} \\
\end{array}$} & \multirow{2}{*}{\begin{tabular}{|l|} 
2-day old \\
$41.67 \pm 1.11 \mathrm{~d}$ \\
\end{tabular}} & \multirow{2}{*}{\begin{tabular}{|l|} 
4-day old \\
$26.67 \pm 1.91 \mathrm{c}$ \\
\end{tabular}} & \multirow{2}{*}{$\begin{array}{l}\text { 6-day old } \\
18.33 \pm 2.03 \mathrm{~d}\end{array}$} \\
\hline \multirow{4}{*}{ Treated } & \multirow{2}{*}{ Haemolymph U/ml) } & mean \pm SD & & & & \\
\hline & & Change (\%) & -23.60 & +127.33 & -15.79 & -45.00 \\
\hline & \multirow{2}{*}{ Fat body (U/ml) } & mean \pm SD & $93.33 \pm 2.99 \mathrm{~d}$ & $103.33 \pm 2.11 \mathrm{~d}$ & $113.36 \pm 3.05 \mathrm{~d}$ & $148.51 \pm 2.77 \mathrm{a}$ \\
\hline & & Change (\%) & +30.22 & +31.92 & +36.00 & +1.13 \\
\hline \multirow{2}{*}{ Control } & Haemolymph U/ml) & mean \pm SD & $48.00 \pm 2.89$ & $18.33 \pm 1.18$ & $31.67 \pm 1.37$ & $33.33 \pm 2.16$ \\
\hline & Fat body (U/ml) & mean \pm SD & $71.67 \pm 3.18$ & $78.33 \pm 2.89$ & $83.33 \pm 1.88$ & $146.67 \pm 2.67$ \\
\hline
\end{tabular}

(a), (d): See footnote of Table (1). (c): See footnote of Table (2). 
Disruptive Effects of Some Novel Chitin Synthesis Inhibitors on the Transaminase Activity in Larval Tissues of Spodoptera Littoralis (Lepidoptera: Noctuidae)

Table6. GPT Activity in Last Instar Larvae of S. littoralis after Treatment with LC $_{50}$ of Diofenolan

\begin{tabular}{|c|c|c|c|c|c|c|}
\hline \multirow{2}{*}{\multicolumn{3}{|c|}{ Tissue }} & \multicolumn{4}{|c|}{ Larval age } \\
\hline & & & 0-day old & 2-day old & 4-day old & 6-day old \\
\hline \multirow{4}{*}{ Treated } & \multirow{2}{*}{ Haemolymph U/ml) } & mean \pm SD & $16.67 \pm 1.55 \mathrm{~d}$ & $18.33 \pm 0.97 \mathrm{a}$ & $21.67 \pm 1.12 \mathrm{~d}$ & $26.67 \pm 2.33 \mathrm{c}$ \\
\hline & & Change (\%) & -65.27 & 0.00 & -31.58 & -19.98 \\
\hline & \multirow{2}{*}{ Fat body (U/ml) } & $\operatorname{mean} \pm \mathrm{SD}$ & $93.33 \pm 2.65 \mathrm{~d}$ & $123.33 \pm 3.44 \mathrm{~d}$ & $148.33 \pm 2.17 \mathrm{~d}$ & $151.67 \pm 2.89 \mathrm{a}$ \\
\hline & & Change (\%) & +30.22 & +57.45 & +78.00 & +3.41 \\
\hline \multirow{2}{*}{ Control } & $\begin{array}{l}\text { Haemolymph } \\
(\mathrm{U} / \mathrm{ml})\end{array}$ & mean \pm SD & $48.00 \pm 2.89$ & $18.33 \pm 1.18$ & $31.67 \pm 1.37$ & $33.33 \pm 2.16$ \\
\hline & Fat body (U/ml) & mean \pm SD & $71.67 \pm 3.18$ & $78.33 \pm 2.89$ & $83.33 \pm 1.88$ & $146.67 \pm 2.67$ \\
\hline
\end{tabular}

(a), (d): See footnote of Table (1). (c): See footnote of Table (2).

\section{DisCUSSION}

Because GOT (=AST) and GPT (=ALT) help in the production of energy and serve as a strategic link between the carbohydrate and protein metabolism, they are being altered during various physiological and pathological conditions [94, 95]. They may also play an important role in the insecticidal poisoning [96]. Various IGRs (including CSIs), were reported as disruptive agents on GOT and/or GPT activities in different insects. Some IGRs prohibited the enzyme activities while other IGRs enhanced them. Moreover, same IGR may enhance or prohibit the enzyme activities depending on the developmental stage of the insect and its tissue [97-100]. Generally, it is assumed that the control of transaminase activities in the insect body is achieved through secondary feed-back or homeostatic mechanisms adapted to spontaneous or hormonally induced alterations [101].

\subsection{Disturbed GOT Activity in Larvae of $S$. littoralis by CSIs}

In the present study on S. littoralis, each of Cyromazine and Diofenolan exhibited a prevalent enhancing effect on GOT activity in haemolymph of last instar larvae of all ages. Novaluron exhibited a similar inducing effect on the enzyme activity except in 4-day old larvae which contained declined level of activity. With regard to fat bodies, remarkably decreasing GOT activity was determined in larvae of all ages, regardless the CSI. The enhanced GOT activity in haemolymph is, to some extent, in agreement with the increasing activity reported for the same insect species after treatment with several IGRs or insecticides, such as hexaflumuron [102], pyriproxyfen, flufenoxuron or teflubenzuron [98], hexaflumuron alone or its binary mixture with chlorpyriphos [103], pyriproxyfen, flufenoxuron or chlorfluazuron [104] and flufenoxuron [105]. In addition to $S$. littoralis, some IGRs enhanced GOT activity in Pectinophora gossypiella [106] and M. domestica [107] by pyriproxyfen as well as in Culex pipiens by Cyromazine [59].

On the other hand, the predominant inhibitory effect of CSIs on GOT activity in fat bodies of larvae, in the present study, is consistent with some of the reported results of decreasing enzyme activity in the same insect species after treatment with diflubenzuron or triflumuron [108], chlorfluazuron [109], hexaflumuron [102], pyriproxyfen, flufenoxuron or chlorfluazuron [104], chlorfluazuron or tebufenozide [110], flufenoxuron or chlorfluazuron [105], etc. Also, GOT activity was prohibited in other insects by some IGRs, such as P. gossypiella and Earias insulana by pyriproxyfen [106], Agrotis ipsilon [111] and Bombyx mori [95] by the same IGR; M. domestica by hexaflumuron or lufenuron [107], C. pipiens by Cyromazine [59]. The general declination of GOT activity in fat bodies of $S$. littoralis after treatment with CSIs, in the present study, may be due to the difficulty in formation of dissociable enzyme-inhibitor complexes which reduce the specific enzyme activity [112] or they disturbed the link between the carbohydrate and protein metabolism.

\subsection{Disturbed GPT Activity in Larvae of $\boldsymbol{S}$. littoralis by CSIs}

In the present study, CSIs exhibited contradictory effects on GPT activity in haemolymph of last instar larvae of S. littoralis since Novaluron elaborately promoted it, with an exceptional case of 6-day old larvae while Cyromazine and Diofenolan treatments resulted in conspicuously declined enzyme level, with few exceptions. Dealing with fat bodies, Cyromazine and Diofenolan enhanced the 
enzyme activity while Novaluron failed to exhibit an effect, irrespective of the larval age. Enhanced GPT activity in haemolymph of larvae by Novaluron or in fat bodies by Cyromazine and Diofenolan is, to a great extent, in accordance with the increasing activity in the same insect by some IGRs and CSIs, such as hexaflumuron [102] and pyriproxyfen, flufenoxuron or chlorfluazuron [104]. Also, stimulated GPT activity was reported for some of other insects by different IGRs, such as $P$. gossypiella and E. insulana [106] and M. domestica [107] by pyriproxyfen as well as Bactrocera zonata by malathion, diazinon, methoxyfenozide or lufenuron [113] and C. pipiens by Cyromazine [59].

On the other hand, declined level of GPT in haemolymph of $S$. littoralis larvae by Cyromazine and Diofenolan, in the present study, agrees with the decreased activity in the same insect by several IGRs and CSIs, such as triflumuron [108], chlorfluazuron [109], hexaflumuron [102], pyriproxyfen, flufenoxuron or teflubenzuron [98], pyriproxyfen, flufenoxuron or chlorfluazuron [104] and flufenoxuron [105]. In other insect species, decreasing GPT activity was reported in P. gossypiella and E. insulana by pyriproxyfen [106], A. ipsilon by the same IGR [95], M. domestica by hexaflumuron or lufenuron [107] and C. pipiens by Cyromazine [59]. The inhibited GPT activity in haemolymph of larvae of $S$. littoralis by Cyromazine and Diofenolan, in the present study, can be understood since pyruvate is the precursors of Krebs cycle compounds, concerned with the mitochondrial oxidation phenomenon and ATP products [94]. However, diverse effects of the tested CSIs on GPT activity in larvae may be due to their effects on the synthesis or functional levels of this enzyme directly or indirectly by altering the cytomorphology of the cells [114] or the neurosecretory hormonal pattern.

The increasing activity of transaminases, in the current work, may be attributed to the occurrence of reversible binding between the tested CSIs and enzymatic site of action on the enzyme surface. This may be due to the fact that the relationships between protein synthesis and transaminase levels were affected by the hormonal control of protein synthesis and neurosecretory hormones which involved in the regulation of transaminase levels [115]. Thus, the present CSIs may intervene in the hormonal control of protein synthesis and neurosecretory hormones involved in the regulation of transaminase levels [116]. However, the exact mode of action of the tested CSIs on transaminase regulation is still controversial until now!!

\section{Conclusion}

The disturbance of transaminase activities by the present CSIs, in the present study, may be lead to disturbance of protein metabolism and synthesis of some specific compounds. Thus, these CSIs will disrupt many physiological functions and ultimately lead to death, i.e., they can be used as a part in the integrated pest management program against this dangerous pest.

\section{REFERENCES}

[1] Miles, M.; and Lysandrou, M. (2002): Evidence for negative cross resistance to insecticides in field collected Spodoptera littoralis (Boisd.) from Lebanon in laboratory bioassays. Mededelingen (Rijksuniversiteitte Gent. Fakulteit van de Landbouwkundige en Toegepaste Biologische Wetenschappen), 67: 665.

[2] Abo El-Ghar, G.E.; Elbermawy, Z.A.; Yousef A.G. and Abd-Elhady, H.K. (2005): Monitoring and characterization of insecticide resistance in the cotton leafworm, Spodoptera littoralis (Boisd.) (Lepidoptera: Noctuidae). J. Asia-Pacific Entomol., 8(4): 397-410.

[3] Aydin, M.H. and Gurkan, M.O. (2006): The efficacy of spinosad on different strains of Spodoptera littoralis (Boisduval)(Lepidoptera: Noctuidae). Tur. J. Bio., 30: 5-9.

[4] Davies, T.G.E.; Field, L.M.; Usherwood, P.N.R. and Williamson, M.S. (2007): DDT, pyrethrins and insect sodium channels. IUBMB Life, 59: 151-162.

[5] Costa, L.G.; Giordano, G.; Guizzetti, M. and Vitalone, A. (2008): Neurotoxicity of pesticides: a brief review. Frontiers BioSci., 13: 1240-1249.

[6] Relyea, R.A. (2009): A cocktail of contaminants: how mixtures of pesticides at low concentrations affect aquatic communities. Oecologia, 159: 363-376.

[7] Mosallanejad, H. and Smagghe, G. (2009): Biochemical mechanisms of methoxyfenozide resistance in the cotton leafworm Spodoptera littoralis. Pest Manage. Sci., 65: 732-736.

[8] Mondal, K.A.M.S.H. and Parween, S. (2000): Insect growth regulators and their potential in the management of stored product insect pests. Integ. Pest Manage. Rev., 5: 255-295. 
[9] Hussain, A. (2012): The effect of non-host plant volatiles on the reproductive behaviour of the Egyptian cotton leafworm, Spodoptera littoralis. M.Sc. Thesis, Swedish Univ. Agric.Sci., Sweden.

[10] Raslan, S.A.A. (2002): Preliminary report on initial and residual mortality of the natural product, Spinosad, for controlling cotton leaf worm egg masses. In: Egypt. $2^{\text {nd }}$ Inter. Conf., Plant Prot. Res. Inst., Cairo, Egypt, 21-24 December, 2002. Vol. 1: 635-637.

[11] Oberlander, H.; Silhacek, D.L.; Shaaya, E. and Ishaaya, I. (1997): Current status and future perspectives of the use of insect growth regulators for the control of stored product pests. J. Stored Prod. Res., 33: 1-6.

[12] Tunaz, H. and Uygun, N. (2004): Insect growth regulators for insect pest control. Turkish J. Agric.Forestry, 28: 337-387.

[13] Cutler, G.C.; Scott-Dupree, C.D.; Tolman, J.H. and Harris, C.R. (2007): Field efficacy of novaluron for control of Colorado potato beetle (Coleoptera: Chrysomelidae) on potato. Crop Prot., 26: 760-767.

[14] Alyokhin, A.; Guillemette, R. and Choban, R. (2009): Stimulatory and suppressive effects of Novaluron on the Colorado potato beetle reproduction. J. Econ. Entomol., 102(6): 2078-2083.

[15] Ishaaya, I. and Horowitz, A.R. (2002): Novaluron (Rimon) a novel IGR: its biological activity and importance in IPM programs. Phytoparasitica, 30: 203.

[16] Tomlin, C.D.S. (1997): Novaluron. In: "The Pesticide Manual" (Tomlin, C.D.S., ed.). $11^{\text {st }}$ ed. British Crop Protection Council, UK, pp: 888-889.

[17] Ishaaya, I. and Horowitz, A.R. (1998): Insecticides with novel modes of action: an overview. In: (Ishaaya, I. and Degheele, D., eds) "Insecticides with Novel Modes of Action: Mechanism and Application". pp. 1-24. Springer, Berlin.

[18] Cutler, G.C.; Scott-Dupree, C.D.; Tolman, J.H. and Harris, C.R. (2005a): Acute and sublethal toxicity of novaluron, a novel chitin synthesis inhibitor, to Leptinotarsa decemlineata (Coleoptera: Chrysomelidae). Pest Manage. Sci., 61: 1060-1068.

[19] Cutler, G.C.; Tolman, J.H.; Scott-Dupree, C.D. and Harris, C.R. (2005b): Resistance potential of Colorado potato beetle (Coleoptera: Chrysomelidae) to novaluron. J. Econ. Entomol., 98: 1685-1693.

[20] Ishaaya, I.; Kontsedalov, S.; Masirov, D. and Horowitz, A.R. (2001): Biorational agentsmechanism, selectivity and importance in IPM programs for controlling agricultural pests. Med. Landbouww Rijksuniv Gent, 66: 363-374.

[21] Ishaaya, I.; Horowitz, A.R.; Tirry, L. and Barazani, A. (2002): Novaluron (Rimon), a novel IGR: mechanism, selectivity and importance in IPM programs. Proc. Int. Symp. Crop Protect. Med. Fac. Landbouww Univ., Gent, 67: 617-626.

[22] Ishaaya, I.; Kontsedalov, S. and Horowitz, A.R. (2003): Novaluron (Rimon), a novel IGR: Potency and cross-resistance. Arch. Insect Bioch. Physiol., 54: 157-164.

[23] Mulla, M.S.; Tawatsin, A.; Chompoosri, J.; Zaim, M. and Su, T. (2003): Laboratory and field evaluation of novaluron a new acylurea insect growth regulator against Aedes aegypti (Diptera: Culicidae). J. Vector. Ecol., 4: 241-254.

[24] Su, T.Y.; Zaim, M. and Mulla, M.S. (2003): Laboratory and field evaluation of Novaluron, a new insect growth regulator (IGR) against Culex mosquitoes. J. Am. Mosq. Control Assoc., 19: 408- 418.

[25] Arredondo-Jiménez J. I., and Valdez-Delgado K. M., (2006): Effect of Novaluron (Rimon 10 EC) on the mosquitoes Anopheles albimanus, Anopheles pseudopunctipennis, Aedes aegypti, Aedes albopictus and Culex quinquefasciatus from Chiapas, Mexico, Med Vet Entomol.; 20(4):377-87.

[26] Cetin, H.; Erler, F. and Yanikaglu, A. (2006): Larvicidal activity of novaluron, a chitin synthesis inhibitor, against the house fly, Musca domestica. J. Insect Sci., 6: 344-351.

[27] Tawatsin, A.; Thavara, U.; Bhakdeenuan, P.; Chompoosri, J.; Siriyasatien, P.; Asavada cha nukorn, P. and Mulla, S.M. (2007): Field evaluation of novaluron, a chitin synthesis inhibitor larvicide, against mosquito larvae in polluted water in urban areas of Bangkok, Thailand. Southeast Asian J. Trop. Med. Public Health., 38(3): 434-441. 
[28] Mascari, T.M.; Mitchell, M.A.; Rowton, E.D. and Foil, L.D. (2007): Evaluation of Novaluron as a feed-through insecticide for control of immature sand flies (Diptera: Psychodidae). J. Med. Entomol., 44(4): 714-717.

[29] Kostyukovsky, M. and Trostanetsky, A. (2006): The effect of a new chitin synthesis inhibitor, novaluron, on various developmental stages of Tribolium castaneum (Herbst). J.Stored Prod. Res., 42: 136-148.

[30] Kostykovsky, M. and Trostanetsky, A. (2008): Transovarial activity of the chitin synthesis inhibitor novaluron on egg hatch and subsequent development of larvae of Tribolium castaneum. Phytoparasitica, 36: 38-41.

[31] Jambulingam P.; Sanadanandane C.; Nithiyananthan N.; Sbramanian S. and Zaim, M. (2009): Efficacy of novaluron against Culex quinquefasciatus in small- and medium-scale trials, India. J. Am. Mosq. Control Assoc., 25(3): 315-322.

[32] Martin, D.E.; Lopez, Jr. J.D.; Lan, Y.; Fritz, B.K.; Hoffmann, W.C. and Duke, S.E. (2010): Novaluron as an ovicide for bollworm on Cotton: deposition and efficacy of field-scale aerial applications. J.Cotton Sci., 14: 99-106.

[33] Nwankwo, E.N.; Okonkwo, N.J.; Ozumba, N.A.; Okafor, E.G. (2011): Comparative studies on the larvicidal action of Novaluron (Mosquiron ${ }^{\circledR}$ 100EC) and Moringa oliefera (LAM) seed oil against Aedes aegypti (Diptera: Culicidae) larvae. Afr. Res. Rev., 5(1): 424-437.

[34] Bouaziz, A.; Boudjelida, H. and Soltani, N. (2011): Toxicity and perturbation of the metabolite contents by a chitin synthesis inhibitor in the mosquito larvae of Culiseta longiareolata. Ann. Biol. Res. 2(3): 134-143.

[35] Fontoura, N.G.; Bellinato, D.F.; Valle, D. and Lima, J.B.P. (2012): The efficacy of a chitin synthesis inhibitor against field populations of organophosphate-resistant Aedes aegypti in Brazil. Mem. Inst. Oswaldo Cruz, Rio de Janeiro, 107(3): 387-395.

[36] Kamminga, K.L.; Kuhar, T.P.; Wimer, A. and Herbert, D.A. (2012): Effects of the insect growth regulators novaluron and diflubenzuron on the brown marmorated stink bug. Plant Health Progress Online doi:10.1094/PHP-2012-1212-01-RS.

[37] Arthur, F.H. and Fontenot, E.A. (2012): Residual activity of methoprene and novaluron as surface treatments to manage the flour beetles, Tribolium castaneum and Tribolium confusum.J. Insect Sci., 12: 95.

[38] Portilla, M.; Snodgrass, G. and Luttrell, R. (2012): A Novel bioassay using a non-autoclaved solid Lygus diet to evaluate the effect of Beauveria bassiana and the insect growth regulator novaluron on tarnished plant bug, Lygus lineolaris, $3^{\text {rd }}$ international Lygus symposium, Scottsdale, Arizona, USA.

[39] Rajasekar, P. and Jebanesan, A. (2012): Efficacy of IGRs compound Novaluron and Buprofezin against Culex quinquefasciatus mosquito larvae and pupal control in pools, drains and tanks; Int. J. Res. Bio. Sci.; 2 (1): 45-47.

[40] Djeghader, N.; Djeghader, H.; Bouaziz, A. and Soltani, N. (2013): Biological effects of a benzoylphenylurea derivative (Novaluron) on larvae of Culex pipiens (Diptera: Culicidae); Adv. App. Sci. Res., 4(4): 449-456.

[41] Djeghader, N.E.H.; Aïssaoui, L.; Amira, K. and Boudjelida, H. (2014): Impact of a chitin synthesis inhibitor, Novaluron, on the development and the reproductive performance of mosquito Culex pipiens. World Applied Sciences Journal, 29(7): 954-960.

[42] Cutler, G.C.; Scott-Dupree, C.D.; Tolman, J.H. and Harris, C.R. (2006): Toxicity of Novaluron to the non-target predatory bug Podisus maculiventris (Heteroptera: Pentatomidae). Biological Control, 38: 196-204.

[43] Ishaaya, I.; Kontsedalov, S. and Horowitz, A.R., (2005): Biorational Insecticides: Mechanism and Cross-Resistance. Arch. Insect Biochem. Physiol., 58: 192-199.

[44] Awad, T.I. and Mulla, M.S. (1984): Morphogenetic and histopathological effects induced by the insect growth regulator cyromazine in Musca domcstica. J. Med. Entomol., 21(4): 419-426.

[45] Binnington, K.C. (1985): Ultrastructural changes in the cuticle of the sheep blowfly, Lucilia cuprina, induced by certain insecticides and biological inhibitors. Tissue Cell, 17: 131-140.

[46] Saito, T. (1988): Insecticide activity of several chemicals to the bryony Leafminer Liriomyza bryoniae and their application methods. Plant Protect., 35: 168-171. 
Disruptive Effects of Some Novel Chitin Synthesis Inhibitors on the Transaminase Activity in Larval Tissues of Spodoptera Littoralis (Lepidoptera: Noctuidae)

[47] Reynolds, S.E. and Blakey, J.K. (1989): Cyromazine causes decreased cuticle extensibility in larvae of the tobacco hornworm, Manduca sexta. Pestic. Biochem. Physiol., 35: 251-258.

[48] Keiding, J.; El-Khodary, A.S. and Jespersen, J. B. (1992): Resistance risk assessment of two insect development inhibitors, diflubenzuron and cyromazine, for control of the housefly Musca domestica L. Part II: Effect of selection pressure in laboratory and field populations. Pestic. Sci., 35: 27-37.

[49] Viňuela, E.; Budia, F.; Gacas, J.; Adan, A.; Marco, M. and Del Estal, P. (1993): Differential larval age susceptibility of Medfly Ceratitis capitata to cyromazine. J. Appl. Entomol., 115: 355-361.

[50] Viňuela, E. and Budia, F. (1994): Ultrastructure of Ceratitis capitata Wiedemann larval integument and changes induced by IGR Cyromazine. Pestic. Biochem. Physiol., 48: 191-201.

[51] Levot, G.W. and Sastes, N. (1998): Effectiveness of amixture of Cyromazine and Diazinon for controlling fly strike on sheep. Aust. Vet. J., 76(5): 343-344.

[52] Tomlin, C.D.S. (ed.) (2000): The Pesticide Manual, $12^{\text {th }}$ ed. British Crop Protection Council Publications.

[53] Emea (2001): The European Agency for the Evaluation of Medicinal products. Veterinary Medicine and Inspections. 1-5. Enviroment, 6(1): 39-40.

[54] Kamaruzzaman, A.; Reza, A.; Mondal, K. and Parween, S. (2006): Morphological abnormalities in Tribolium castaneum (Herbst) and Tribolium confusum (Duval) due to cyromazine and pirimiphos-methyl treatments alone or in combination, ISJ, 3: 97-102.

[55] Vazirianzadeh, B.; Jervis, M.A. and Kidd, N.A.C. (2007): The effects of oral application of Cyromazine and Triflumuron on house-fly larvae. Iranian J. Arthropod-Borne Dis., 1(2): 7-13.

[56] Darriet, F.; Zaim, M. and Corbel, V. (2008): Laboratory Evaluation of Cyromazine against insecticide-susceptible and -resistant mosquito larvae. J. Am. Mosq. Cont. Assoc., 24(1):123126.

[57] Mediouni-Ben Jemâa, J. and Boushih, E. (2010): Cyromazine induced effects on larvae and adults of laboratory Tunisian strain of the Mediterranean fruit fly Ceratitis capitata. Tuni. J. Plant Prot., 5: 213-222.

[58] Al-Mekhlafi, F.; Mashaly, A.M.; Abdel Mageed, A.; Wadaan, M.A. and Al-Mallah, N.M., (2011): Overlap effects of cyromazine concentration, treatment method and rearing temperature on the Southern cowpea weevil (Callosobruchus maculatus F.) reared on cowpea. Afr. J. Microbiol. Res., 5(32): 5848-5853.

[59] Assar, A.A.1.; Abo-El-Mahasen, M.M.; Harba, N. and Rady, A.A. (2012): Biochemical effects of Cyromazine on Culex pipiens larvae (Diptera: Culicidae). J. Am. Sci., 8(5): 443-450.

[60] Taylor, D.B.; Friesen, K.; Zhu, J.J. and Sievert, K. (2012): Efficacy of Cyromazine to control immature stable flies (Diptera: Muscidae) developing in winter hay feeding sites. J. Econ. Entomol., 105(2): 726-731.

[61] Beitia, F.; Garrido, A. and Castaner, M. (1991): Mortality produced by various pesticides applied to eggs of Diglyphus isaea (Walker) (Hym.: Eulophidae) in laboratory tests. Ann. Appl. Biol., 118 (Suppl.): 16-17.

[62] Schuster, D.J. (1994): Life-stage specific toxicity of insecticides to parasitoids of Liriomyza trifolii (Burgess) (Diptera: Agromyzidae). Int. J. Pest Manage., 40: 191-194.

[63] Graf, J.F. (1993): The role of insect growth regulators in arthropod control. Parasitol. Today, 9: 471-474.

[64] Wouw, A.P. Van De; Batterham, Ph.andDaborn, Ph.J. (2006): The insect growth regulator insecticide cyromazine causes earlier emergence in Drosophila melanogaster. Arch. Insect Bioch. Physiol., 63(3): 101-109.

[65] Streibert, H.P.; Frischknecht, M.L. and Karrer, F. (1994): Diofenolan - a new insect growth regulator for the control of scale insects and important lepidopterous pests in deciduous fruits and citrus. Proc. Brighton Crop Prot. Conf., Pests and Dis., 1:23-30.

[66] Paloukis, S.S. and Navrozidis E.I. (1995): Effectiveness of a new insecticide (diofenolan) for control of San Jose scale, Quadraspidiotus perniciosus (Comstock) (Diaspididae), on peach trees in northern Greece; Isr. J. Entomol., 29: 285-286. 
[67] Dhadialla, T.S., Carlson, G.R. and Le, D.P. (1998): New insecticides with ecdysteroidal and juvenile hormone activity. Annu. Rev. Entomol. 43: 545-569.

[68] Singh, S. and Kumar, K. (2011): Diofenolan: a novel insect growth regulator in common citrus butterfly, Papilio demoleus. Phytoparasitica, 39(3): 205-213.

[69] Ghoneim K.S.; Bream A.S.; Tanani M.A. and Nassar M.M. (2001): Effectiveness of IGRS (CGA-184699) and (CGA-259205) on the respiratory metabolism of the red palm weevil, Rhynchophorus ferrugineus (Coleoptera: Curculionidae). Mededelingen (Rijksuniversiteitte Gent. Fakulteit van de Landbouwkundige en Toegepaste Biologische Wetenschappen), 66(2a): 413-423.

[70] Ghoneim, K.S.; Al-Dali, A.G. and Abdel-Ghaffar, A.A. (2003): Effectiveness of Lufenuron (CGA-184699) and Diofenolan (CGA-59205) on the general body metabolism of the red palm weevil, Rhynchophorus ferrugineus (Curculionidae: Coleoptera). Pakistan J.Biol.Sci., 6(13): 1125-1129.

[71] Amer, M.S.; Ghoneim, K.S.; Abdel-Ghaffar, A.A.; Al-Dali, A.G.; Bream, A.S. and Hamadah, Kh.Sh. (2006): Reproductive potentiality of Musca domestica (Diptera: Muscidae) as affected by two chitin synthesis inhibitors: Lufenuron and Diofenolan. Al-Azhar Bull.Sci., 17(2): 67-75.

[72] Al-Dali, A.G. (2008): Transaminase activity in Musca domestica (Diptera: Muscidae) as affected by some insect growth regulators. $18^{\text {th }}$ Inter. Conf. Egypt. Ger. Soc. Zool., 1-5 March, 56(A): 1-19.

[73] Ghoneim, K.S.; Amer, M.S.; Bream, A.S.; Al-Dali, A.G. and Hamadah, Kh.Sh. (2004): Developmental and morphogenic responses of the house fly Musca domestica to the CSIs: Lufenuron and Diofenolan. Al-Azhar Bull.Sci., 15(2): 25-42.

[74] Bakr, R.F.; Ghoneim, K.S.; Al-Dali, A.G.; Tanani, M.A. and Bream, A.S. (2008): Efficiency of the chitin synthesis inhibitor lufenuron (CGA-184699) on growth, development and morphogenesis of Schistocerca gregaria (Orthoptera: Acrididae). Egypt. Acad. J. Biol. Sci., 1(1): $41-57$.

[75] Ghoneim, K.S.; Hamadah, Kh.Sh. and Tanani, M.A. (2012): Protein disturbance in the haemolymph and fat body of the desert locust Schistocerca gregaria as a response to certain insect growth regulators. Bull. Environ. Pharmacol. Life Sci., 1(7): 73- 83.

[76] Hamadah, Kh.Sh.; Ghoneim, K.S. and Tanani M.A. (2012): Effect of certain insect growth regulators on the lipid content of some tissues of the desert locust Schistocerca gregaria. Afr. J. Biochem. Res., 6(9): 121-128.

[77] Tanani, M.A; Ghoneim, K.S. and Hamadah, Kh.Sh. (2012): Comparative effects of certain IGRs on the carbohydrates in haemolymph and fat body of the desert locust, Schistocerca gregaria (Orthoptera: Acrididae). Florida Entomologist, 95(4): 928-935.

[78] Sechser, B.; Reber, B. and Wesiak, H. (1994): Selectivity of diofenolan (CGA-59205) and its potential for integrated scale control. Proc. Brighton Crop Prot. Conf. Pests and Dis., 3: 11931198.

[79] Gilmour, D. (1965): The metabolism of insects. Olver \& Boyd, Edinburgh and London.

[80] Mordue, W. and Goldsworthy, G.J. (1973): Transaminase levels and uric acid production in adult locusts. Insect Biochem., 3: 419-427.

[81] Katumuma, N.; Okada, M.; Katsumua, T., Fujino, A. and Matsuzawa, T. (1968): Different metabolic rates of tranaminases isozymes. In: "Pyridoxal catalysis: Enzymes and Model systems" (Shell, E.E.; Braunstein, A.E.; Severin, E.S. and Torchin Sky, Y.M., eds.). Inter Science, New York.

[82] Shonouda, M.L. and Osman, S.L. (2000): New botanical derivatives, used in medicinal preparations, showing bioactive action on insect pests.1-Toxicological effect on the development of Spodoptera littoralis (Boisduval) (Lepidoptera: Noctuidae). J. Egypt. Ger. Soc. Zool., 31: 227-234.

[83] Brown, E.S. and Dewhurst, C.F. (1975): The genus Spodoptera (Lepidoptera, Noctuidae) in Africa and the Near East. Bull. Ent. Res., 65: 221-262.

[84] Hosny, M.M.; Topper, C.P.; Moawasd, G.G. and El-Saadany, G.B. (1986): Economic damage threshold of Spodoptera littoralis (Boisd.) (Lepidoptera: Noctuidae) on cotton in Egypt. Crop Protection, 5: 100-104. 
[85] Bayoumi, A.E.; Balaña-Fouce, R.; Sobeiha, A.K. and Hussein, E.M.K. (1998): The biological activity of some chitin synthesis inhibitors against the cotton leafworm Spodoptera littoralis (Boisduval), (Lepidoptera: Noctuidae). Boletín de Sanidad Vegetal, Plagas, 24(3): 499-506.

[86] Salama, H.S.; Salem, S.A.; Zaki, F.N. and Shams EL-din, A. (1990): Comparative effectiveness of Bacillus thuringiensis and lannate against Spodoptera littoralis. J. Islam. Acad. Sci., 3: 325329.

[87] Azab, S.; Sadek, M. and Crailsheim, K. (2001): Protein metabolism in larvae of the cotton leafworm Spodoptera littoralis (Lepidoptera: Noctuidae) and its response to three mycotoxins. Envir. Ent., 30: 817-823.

[88] El-Aswad, A.F.; Abdelgaleil, S.A.M. and Nakatani, M. (2003): Feeding deterrent and growth inhibitory properties of limonoids from Khaya senegalensis against the cotton leafworm, Spodoptera littoralis. Pest Manage. Sci., 60:199-203.

[89] Pineda, S.; Schneider, M.I.; Smagghe, G.; Martinez, A.M.; Del Estal, P.; Vinuela, E.; Valle, J. and Budia, F. (2007): Lethal and sublethal effects of methoxyfenozide and spinosad on Spodoptera littoralis (Lepidoptera: Noctuidae). J. Econ. Entomol., 100(3): 773-780.

[90] Ghoneim, K.S. (1985): Physiological studies on endocrine and reproductive systems of the cotton leafworm Spodoptera littoralis (Boisd.) (Lepidoptera: Noctuidae). Ph.D. Thesis, Fac. of Sci., Al-Azhar Univ., Cairo, Egypt.

[91] Bakr, R.F.A.; El-barky, N.M.; Abd Elaziz, M.F.; Awad, M.H. and Abd El-Halim, H.M.E. (2010): Effect of Chitin synthesis inhibitors (flufenoxuron) on some biological and biochemical aspects of the cotton leaf worm Spodoptera littoralis Bosid. (Lepidoptera: Noctuidae). Egypt. Acad. J. Biolog. Sci., 2(2): 43-56.

[92] Harold, V. (1975): Practical Clinical Biochemistry. $4^{\text {th }}$ ed., Arnold-Heinemann Publishers (India) Private Limited, India. pp. 294.

[93] Moroney, M.J. (1956): Facts from figures ( $3^{\text {rd }}$ ed.). Penguin Books Ltd., Harmondsworth. Middle Sex.

[94] Azmi, M.A.; Sayed, N.H. and Khan, N.F. (1998): Comparative topological studies of RB-a (Neem Extract) and Coopex (Permethrin + Bioallethrin) against Sitophilus oryzaewith reference to their effects on oxygen consumption and GOT and GPT activity. J. Zool., 22: 307-310.

[95] Etebari, K.; Bizhannia, A.R.; Sorati, R. and Matindoost, L. (2007): Biochemical changes in haemolymph of silkworm larvae due to pyriproxyfen residue. Pestic. Biochem. Physiol., 88: 1419.

[96] Abd El-Mageed, A.E.M. (2002): Toxicological and analytical studies on some insecticides. PhD Thesis, Fac. Agric, Mansoura Univ., Egypt.

[97] Saha, L.M.; Mandal, S. and Choudhuri, D.K. (1986): The effect of juvenile hormone analogue and ecdysterone on the fat body of female Chrysocoris stolliWolf (Pentatomidae: Heteroptera: Hemiptera). Zoologische Jahrbucher, Abteilung fur Allgemeine Zoologie und Physiologic der Tiere., 90(1): 85-100.

[98] El-Kordy, M.W.; Gadallah, A.I.; Abbas, M.G. and Mostafa, S.A. (1995): Effect of pyriproxyfen, flufenoxuron and teflubenzuron on some biochemical aspects of Spodoptera littoralis. Al-Azhar J. Agric. Res., 21: 223-238.

[99] Tabassum, R.; Naqvi, S.N.H.; Jahan, M., Nurulain, S.M.; Khan, M.F. and Azmi, M.A. (1998): Determination of toxicity of fenpropathrin and neem formulation (RB-a+PBO+Tx-100) and its effect on transaminases (GOT, GPT) against Alphitobius diaperinus adults. Turk. J. Zool., 22(4): 319-322.

[100] Bakr, R.F.; El bermawy, S.; Emara, S.; Abulyazid, I. and Abdel-Wahab, H. (2002): Biochemical studies on Spodoptera littoralis developmental stages after larval treatment with different botanical extracts. Proceeding of $2^{\text {nd }}$ Int. Conf. Plant Prot. Res. Inst., Cairo, Egypt, (1): 888-893.

[101] Nohel, M.P.H. and Salama, R. (1972): Effects of a juvenile hormone on glutamate-pyruvate transaminase activity in the bug Pyrrhocoris apterus. Insect Biochem., 2: 58- 66.

[102] Sokar, L.A. (1995): Possible alternatives to classical insecticides in management program of Spodoptera littoralis (Boisd.). Ph.D. Thesis, Zagazig Univ., Egypt. 
[103] Mohamed, H.A. and Azab, A.M. (2002): Effect of insect growth regulators and binary mixtures on enzymes activity of Egyptian cotton leaf worm, Spodoptera Littoralis, (Boisd) Larvae. Proceeding of $2^{\text {nd }}$ Int. Conf. Plant Prot. Res. Inst., Cairo, Egypt, 1: 617-622.

[104] Abdel-Aal, A.E. (2003): Effect of some insect growth regulators on certain biological, biochemical and histopathological aspects of the cotton leafworm, Spodoptera littoralis (Boisd.) Ph.D. Thesis, Fac. Sci., Cairo Univ., Egypt.

[105] Zohry, N.M. (2006): Aberration of some Insecticides on some biological aspects of the cotton leafworm Spodoptera littoralis (Lepidoptera: Noctuidae). Ph.D. Thesis, Fac. Sci., Ain Shams Univ., Cairo, Egypt.

[106] Anan, A.R.; Mohamed, M.I. and Hussein, N.M. (1993): Biochemical effect of pyriproxyfen juvenoid on fat and haemolymph proteins of pink bollworm, Pectinophora gossypiella (Saund.) and spiny bollworm, Earias insulana (Boisd.).Ann. Agric. Sci., Ain Shams Univ., Egypt, 38: 761-72.

[107] Assar, A.A.; Abo El-Mahasen, M.M.; Khalil, M.E. and Mahmoud, S.H. (2010): Biochemical effects of some insect growth regulators on the house fly, Musca domestica (Diptera: Muscidae). Egypt. Acad. J. Biolog. Sci., 2(2): 33-44.

[108] Abdel-Hafez, M.M.; Shaaban, M.N.; El-Malla, M.A.; Farag, M. and Abdel-Kawy, A.M. (1988): Effect of insect growth regulators on the activity of transaminases enzymes with reference to protein and amino acids in the Egyptian cotton leafworm Spodoptera littoralis (Boisd.). Minia J. Agric. Res. \& Dev., 10(3): 1357-1372.

[109] Ahmed, Y.M.; Mostafa, A.M. and Shoukry, A. (1990): Effect of chlorfluazuron on transaminases activities in the larvae and pupae of Spodoptera littoralis. Rijksuniversiteit Gent., 55(2b): 621-627.

[110] Anwar, E.A. and Abd El-Mageed, A.E. (2005): Toxicity impacts of certain growth regulators on some biochemical activities of the cotton leaf worms. Egypt. J. Res., 83(3): 912-935.

[111] El-Sheikh, T.A.A. (2002): Effects of application of selected insect growth regulators and plant extracts on some physiological aspects of the black cutworm, Agrotis ipsilon (Huf.). Ph.D. Thesis, Fac. Sci., Ain Shams Univ., Egypt.

[112] Dragomirescu, A.; Raileanu, L.; Ababei, L. (1979): The effect of carbetox on glycolysis and the activity of some enzymes in carbohydrate metabolism in the fish and rat liver. Water. Res., 9: 205.

[113] Mosleh, Y.Y.; Yousry, L.H. and Abo-el-elaa, A. (2011): Toxicological and biochemical effects of some insecticides on peach fly, Bactrocera zonata (Diptera: Tephritidae). Plant Protect. Sci., 47(3): 121-130.

[114] Nath, S.B. (2000): Changes in carbohydrate metabolism in hemolymph and fat body of the silkworm, Bombyx mori L., exposed to organophosphorus insecticides. Pestic.Biochem.Physiol., 68(3): 127-137.

[115] Etebari, K.; Mirhodeini, S.Z. and Matindoost, L. (2005): A study on intraspecific biodiversity of eight groups of silkworm (Bombyx mori) by biochemical markers. Insect Science, 12: 87-94.

[116] Abulyazid, I.; Mahmoud, S.M.; Elshafei, A.M. and Taha, R.H. (2005): Physiological changes of irradiated and diseased mulberry silkworm. Bombyx mori. Egypt. J. Agric. Res, 83(4): 14311445. 